\title{
SPATIAL AND TEMPORAL VARIATION IN HYDROLOGIC CHANGE DUE TO REGULATION AND TRIBUTARY CONTRIBUTIONS ON THE SNAKE RIVER IN Grand Teton National Park WY
}

\author{
NiCHOLAS C. NELSON \OHN C. SCHMIDT \\ DEPARTMENT OF AQUATIC, WATERSHED AND EARTH RESOURCES \\ UTAH STATE UNVERSITY — LOGAN
}

\section{$\downarrow \quad$ INTRODUCTION}

Channel and floodplain form are primarily determined by the flux of water through a reach and the associated transport of the sediment delivered from the upstream watershed. The dominant paradigm of fluvial geomorphology is that the size of the bankfull channel and the characteristics of the adjacent floodplain are maintained by the current hydrologic and sediment supply regimes (Wolman and Miller, 1960; Andrews, 1980; Leopold, 1994). The linkage among flow regime, sediment supply, and channel and floodplain form is well illustrated on regulated rivers where the flow regime and sediment supply are altered by dams. Bed incision under conditions of sediment deficit has been widely described (Mostafa, 1957; Komura and Simmons, 1967; Galay, 1983; Williams and Wolman, 1984). The longitudinal change from near-dam sediment deficit to sediment surplus further downstream has been described by Andrews (1984) and Grant et al. (2003), although local differences in bed texture, channel organization, and valley confinement affect the magnitude of channel and floodplain change in any specific reach (Lagasse, 1981; Grams and Schmidt, 2002, 2005).

Relatively few studies have described the characteristics of channel change under conditions of sediment surplus. The sequence of bed aggradation and narrowing has been described by Everitt (1993) for the Rio Grande along the Texas/Mexico border upstream from Presidio, TX, and by Church (1995) for the Peace River in British Columbia and Alberta, Canada. A significant length of the Trinity River in California is in sediment surplus, as described in numerous agency reports (e.g., U.S. Fish and Wildlife Service and Hoopa Valley Tribe, 1999).

The purpose of this paper is to describe patterns of hydrologic change downstream from Jackson Lake Dam (JLD) and to introduce channel change and bed mobility study methods for which analyses are not yet complete. Because this dam, originally constructed in 1908 and rebuilt in 1916, increased the elevation of an existing, glaciallyscoured Pleistocene lake, the dam caused no change in the downstream supply of sediment. Thus, decreased flood magnitudes inevitably lead to sediment surplus, although the magnitude of this surplus is unknown. Though Mills (1991) and Marston et al. (2005) described large-scale changes caused by JLD on the same part of the Snake River described here, they failed to explicitly characterize the hydrology of most of the study area because they did not account for tributary inflows that alter the flow regime initially created by dam releases. Mills (1991) and Marston et al. (2005) also did not take advantage of estimates of the mean daily discharge in the absence of JLD that allow more precise characterization of stream flow alteration in most of the study area. Mills (1991) and Marston et al. (2005) analyzed aerial photographs as recent as 1989, and we supplemented their work by 
analyzing more recent photographs within an improved geographic information system (GIS) framework.

\section{STUDY AREA}

The study area extends $43 \mathrm{~km}$ between JLD and Moose, WY, and significant changes in stream flow and sediment supply occur over this distance (Figure 1). The contributing drainage area more than doubles from $2090 \mathrm{~km}^{2}$ at the dam to $4343 \mathrm{~km}^{2}$ at Moose, and much of this increase is related to two large tributaries. Pacific Creek and Buffalo Fork join the Snake River within $8 \mathrm{~km}$ of the dam, and their combined watershed area is one third of the total Snake River watershed upstream from Moose. Thus, the influence of dam operations on the flow regime of the Snake River is mitigated by these unregulated tributaries. Three smaller tributaries join the Snake River further downstream: Spread Creek at $14.5 \mathrm{~km}$ downstream from JLD, Cottonwood Creek at $40.5 \mathrm{~km}$, and Ditch Creek at $41.6 \mathrm{~km}$.

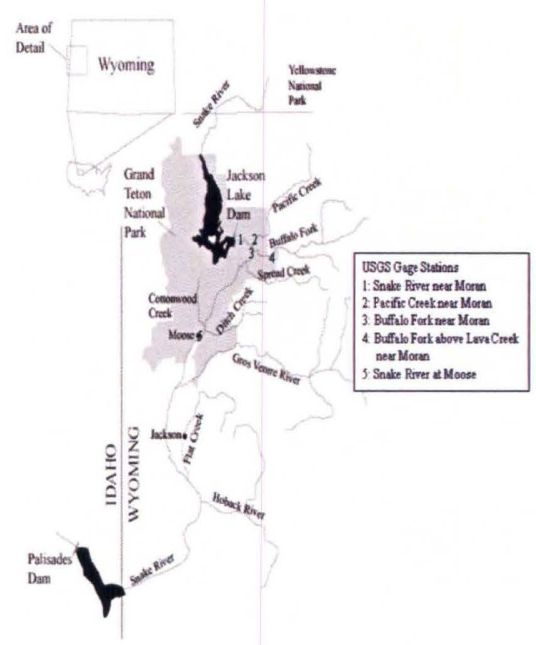

Figure 1: The Snake River as it flows from Yellowstone National Park to Palisades Reservoir. The study reach is from Jackson Lake Dam to Moose.

The Snake River is a braided channel and its adjacent floodplains and low terraces are best described as Class B, medium-energy, and noncohesive, using the classification scheme of Nanson and Croke (1992). Channel organization alternates between single-threaded in a narrow Holocene alluvial valley and multi-threaded in a wider valley or immediately downstream from some tributaries (Marston et al., 2005). Using visual estimation methods along 372 transects, Mills (1991) and Marston et al. (2005) found that the gradient and proportion of large bed material and riffles and rapids increases downstream. Marston et al. (2005) divided the study area into 5 reaches based on location of tributaries, access points, and significant changes in channel morphology. Love et al. (2003) divided the same area into three reaches, based on the response of the river to its glacial history and changing gradient.

Prior to the completion of Palisades Dam on the Snake River in Idaho in 1958, the magnitudes of peak flows on the Snake River downstream from JLD resembled natural flows but were delayed 2 months (Marston et al., 2005). Winter base flows were nearly non-existent during these decades. Peak flows were restored to their natural timing (mid-May to mid-June) after Palisades Dam was completed, but the magnitude of peak dam releases was decreased and summer flows were increased to sustain the recreational boating industry. Marston et al. (2005) described changes in the Snake River hydrology by creating residual mass curves computed from the measured mean daily flows at the U. S. Geological Survey gauging station immediately downstream from the dam (Snake River near Moran, station number 13011000) and they estimated mean monthly unregulated flows based on changes in end-of-month reservoir storage data. We used estimated unregulated mean daily discharge values from 1910 to 2005 , calculated by the U.S. Bureau of Reclamation for the Snake River downstream from JLD to more precisely compare regulated and estimated unregulated flows throughout the study area (<http://www.usbr.gov/pn/hydromet/arcread.html >).

Mills (1991) and Marston et al. (2005) determined that total sinuosity had increased during the $20^{\text {th }}$ century, based on analysis of 7 topographic map or aerial photograph series between 1899 and 1989. They considered total sinuosity to be a surrogate metric of channel stability. They determined that total sinuosity was greatest near tributaries and where the alluvial valley was widest. A composite map of channel location, created in a raster-based GIS, indicated a large number of cells in the floodplain immediately downstream from tributaries that had been recently (as of 1989) active, suggesting that the channel was unstable near tributaries whose delivered sediment load could not be transported by the damregulated flood regime (Marston et al., 2005). These findings were based on an imprecise GIS whose raster cells had widths and lengths comparable to the average width of the Snake River channel at base flow - 80.5 $\mathrm{m}$.

\section{$\downarrow$ METHODS}

\section{Hydrology}

The hydrology of the study area was estimated for four segments defined by the locations of 
tributaries: JLD to Pacific Creek (Segment 1), Pacific Creek to Buffalo Fork (Segment 2), Buffalo Fork to Ditch Creek (Segment 3), and Ditch Creek to Moose (Segment 4) (Figure 2). Gauging stations have directly measured stream flow at the dam since 1903 and at Moose (Snake River at Moose, station number 130136500) since 1995. Elsewhere, and for other periods, main-stem stream flow was estimated by adding measured tributary inflow or by correlation of measured periods and application of that correlation to unmeasured periods. Tributary inflow has been measured at Pacific Creek (Pacific Creek at Moran, station number 13011500) and at Buffalo Fork since 1944 , although the gage was moved from the mouth (Buffalo Fork near Moran, station number 13012000) to upstream from Lava Creek (Buffalo Fork above Lava Creek near Moran, station number 13011900) in 1965. We estimated inflow from the entire Buffalo Fork watershed by multiplying the unit runoff for the upstream gage to the entire watershed area for the post-1965 period:

$$
\mathrm{Q}_{\text {mouth }}=\left(\mathrm{Q}_{\text {above LC }} / \mathrm{A}_{\text {above LC }}\right) \mathrm{A}_{\text {mouth }} \text { (1) }
$$

where $\mathrm{Q}$ is mean daily discharge, $\mathrm{A}$ is drainage basin area, and the subscripts refer to the location of the gages at the mouth $($ mouth $)$ and upstream from Lava Creek (above LC). Only sporadic and incomplete inflow data are available for other tributaries.

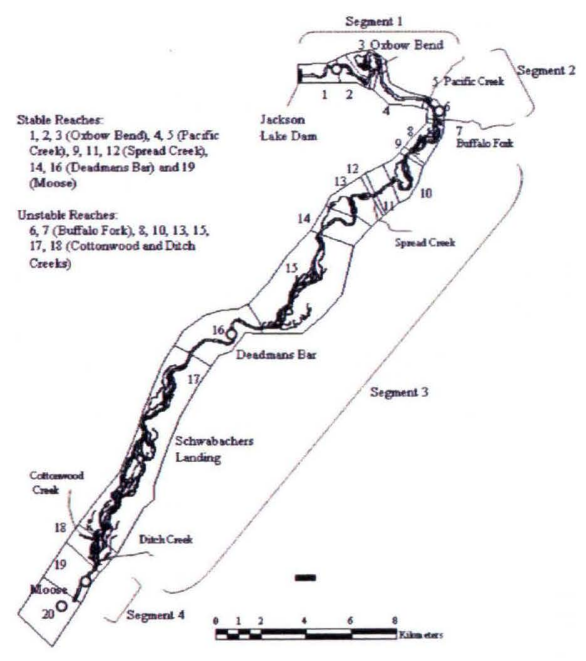

Figure 2. Map of the Snake River from JLD to Moose. The four segmats are the portions of the of the river analyzed for hydrologic change, numbers refer to reaches analyzed for channel change, outlined with think black lines, hollow circles are location of paited rock, the river channel is that of 2002 . :

We added daily inflows from Pacific Creek and Buffalo Fork to daily data at the dam to estimate main-stem mean daily discharge since 1944 upstream from Ditch Creek. We calculated the least-square linear regression between the estimated flow upstream from Ditch Creek and that measured at Moose for the period since 1995 and estimated flows at Moose since 1944 by application of the regression equation. We established the correlation between flows at the dam and between Pacific Creek and Buffalo Fork for the period since 1944 and estimated flows in this segment since 1916 by application of this correlation to the mean daily discharge at the dam. We estimated flows further downstream in a similar fashion by correlation of estimates for an overlapping period and application of this correlation to the 1916-1944 estimates for the upstream segment. The $\mathrm{R}^{2}$ values of each regression equation exceeded 0.93 (Table 1). We did not analyze flows prior to 1916 because the 13 years of record consisted of 5 years of natural flows, 3 years of flows regulated by a log-crib dam, and 5 years of flows during construction of the larger dam and did not represent a stable flow regime suitable for analysis.

\begin{tabular}{ccc}
$\begin{array}{c}\text { Two data series used } \\
\text { to create regression }\end{array}$ & $\begin{array}{c}\text { Regression for Mean } \\
\text { Daily Flows }\end{array}$ & $\mathrm{R}^{2}$ \\
\hline Segments 1,2 & $\mathrm{y}=1.1083 \mathrm{x}+105.19$ & 0.9441 \\
Segments 2, 3 & $\mathrm{y}=1.3005 \mathrm{x}+91.855$ & 0.9306 \\
Segments 3, 4 & $\mathrm{y}=1.0987 \mathrm{x}+280.97$ & 0.9877
\end{tabular}

Table 1: Linear regressions used to estimate flows for the Snake River for Segments 2-4.

Flood frequency was estimated for the maximum mean daily discharge. Calculation of maximum mean daily discharge for each segment provides comparable data not confounded by the addition of instantaneous and mean daily data, because the measured instantaneous annual peak flow immediately downstream from JLD rarely occurred on the same day as the annual instantaneous peak of the tributaries. Estimates of maximum mean daily discharge are also better compared with unregulated conditions, because estimates of annual instantaneous peak flow released from the dam have not been made. The difference between instantaneous and mean daily peak flows is small; the instantaneous annual peak flow was typically less than $5 \%$ greater than the maximum mean daily discharge for the Snake River at the dam and at Moose. Flood recurrences were calculated for the Log-Pearson Type III distribution (Linsley et al., 1982). Because bias and error influenced station estimates of the skew coefficient used in these calculations, especially as the number of observations in the series decreased, we calculated a weighted coefficient of skewness (IACWD, 1982). We obtained the regional skewness factor, -0.1 , from a map of generalized skew coefficients for the United States and used the variance in regional skew, 0.302, estimated for the United States (IACWD 1982). The duration of mean daily flows for each segment were also determined. 


\section{Channel Change}

Channel location and surface area were mapped on 4 aerial photographs or orthophotography (Table 2), and these data were entered into a GIS. We mapped the water surface and also estimated the area of the bankfull channel, because the surface area of the flow is partly dependent on discharge. The edges of the bankfull channel were defined as the boundary between vegetated surfaces and the water or between the floodplain and unvegetated deposits. Thus, the bankfull channel includes the mapped flow area at the time of photography and unvegetated, mid-channel and bank-attached gravel bars adjacent to the floodplain.

\begin{tabular}{ccccc} 
& \multicolumn{4}{c}{ Discharge $\left(\mathrm{m}^{3} / \mathrm{s}\right)$} \\
\hline Image Date & Segment & Segment & Segment & Segment \\
& 1 & 2 & 3 & 4 \\
\hline $7 / 1 / 1945$ & 81.3 & 97.1 & 136.4 & 157.9 \\
$9 / 8 / 1969$ & 73.9 & 75.4 & 82.7 & 98.8 \\
$8 / 7 / 1990$ & 53.8 & 55.9 & 68.6 & 83.4 \\
$7 / 4 / 1991$ & 56.1 & 63.0 & 121.6 & 141.6 \\
$7 / 10 / 2002$ & 70.2 & 75.0 & 106.4 & 126.6
\end{tabular}

Table 2: Mean daily discharges for each segment of the Snake River below JLD for dates of photograph series

The aerial photographs were orthorectified by matching fixed locations such as road junctions, trees, buildings, and distinct landscape elements common to the aerial photographs and orthophotographs. Two main sources of error were inherent in orthorectification (Table 3). First, there was error associated with initial mapping and digitizing of the channel. This error was quantified by calculating the product of the half width of a pencil line $(0.15 \mathrm{~mm})$ and the scale of the aerial photograph. Second, there was error associated with orthorectifying the photographs. The root mean square (RMS) error of each tic for each photograph in each series was calculated. Average RMS errors were less than $1 \mathrm{~m}$ for each photograph series. The total linear error inherent in mapping the channel and orthorectifying the aerial photographs was determined by calculating the square root of the sum of the squares of each error (Geauman et al., 2003). For error calculations of channel width, the total linear error was doubled to account for linear error on both sides of the channel. These are conservative error calculations as other, smaller, sources of error not included in this analysis may be associated with digitizing and overlaying layers in a GIS (Geauman et al., 2003, 2005).

We integrated these data with the GIS data of Mills (1991) for 1975 and 1989. However, the data of the earlier studies could not be ortho-rectified into our data base with acceptable precision, and we compared the spatially averaged values with those that we computed.

\begin{tabular}{ccccc}
$\begin{array}{c}\text { Year of } \\
\text { Aerial } \\
\text { Photograph }\end{array}$ & $\begin{array}{c}\text { Scale of } \\
\text { Photograph }\end{array}$ & $\begin{array}{c}\text { Mapping } \\
\text { Error (m) }\end{array}$ & $\begin{array}{c}\text { RMS } \\
\text { Error }(\mathrm{m})\end{array}$ & $\begin{array}{c}\text { Total } \\
\text { Linear } \\
\text { Error } \\
(\mathrm{m})\end{array}$ \\
\hline 1945 & $1: 56,000$ & 8.4 & 0.94 & 8.45 \\
1969 & $1: 16,000$ & 2.4 & 0.93 & 2.57 \\
$1990 / 1991$ & $1: 56,000$ & 8.4 & 0.67 & 8.43 \\
2002 & $1: 12,000$ & 1.8 & $0.00^{*}$ & 1.80
\end{tabular}

Table 3: Error associated with mapping the channel and orthorectifying the aerial photographs. RMS $=$ root mean square. See text for details.

* There was no RMS error for 2002 because these photos were digital and mapping of the channel was completed solely on the computer.

We developed several metrics to describe channel change. These metrics included channel activity, bankfull channel width, and braid index. Channel activity is defined as the total area, per unit longitudinal distance, of channel erosion and deposition per year. Erosion and deposition were determined by overlay of channel position maps within the GIS and determining changes of floodplain to channel and channel to floodplain between different years. Bankfull channel width was defined as the bankfull channel area divided by the reach length. We also estimated the bankfull area from the Mills (1991) maps for 1975 and 1989, although the dimensions of the bankfull channel were not explicitly mapped. Bankfull area was estimated by scaling the Mills (1991) data by the ratio of water surface to bankfull area. We calculated this ratio for 1945 and $1990 / 1991$, which were the two photograph series in which our data was based on the same (1945), or similar (1989 and 1990/91), data to those of Mills (1991) (Table 4). Since the braid index is the ratio of total channel length to main channel length (Church, 1995), no scaling was necessary to calculate the braid index from our data base or that of Marston et al. (2005).

\begin{tabular}{cccccc}
$\begin{array}{c}\text { Year of } \\
\text { Aerial } \\
\text { Photo }\end{array}$ & $\begin{array}{c}\text { Marston } \\
\text { et al. } \\
\text { (water's } \\
\text { edge) }\end{array}$ & $\begin{array}{c}\text { This study } \\
\text { (water's } \\
\text { edge) }\end{array}$ & $\begin{array}{c}\text { This } \\
\text { study } \\
\text { (bankfull) }\end{array}$ & $\begin{array}{c}\text { Marston's } \\
\text { water's } \\
\text { edge vs. } \\
\text { this } \\
\text { study's } \\
\text { bankfull }\end{array}$ & $\begin{array}{c}\text { Marston et } \\
\text { al. } \\
\text { (recalculated } \\
\text { for bankfull) }\end{array}$ \\
\cline { 2 - 6 } & Area $\left(\mathrm{m}^{2}\right)$ & Area $\left(\mathrm{m}^{2}\right)$ & Area $\left(\mathrm{m}^{2}\right)$ & $\begin{array}{c}\% \\
\text { Difference }\end{array}$ & Area $\left(\mathrm{m}^{2}\right)$ \\
\hline 1945 & $4,501,786$ & $5,107,579$ & $5,930,512$ & 31.74 & $5,857,142$ \\
1975 & $4,316,403$ & -- & -- & -- & $5,615,945$ \\
1989 & $4,398,948$ & -- & -- & -- & $5,723,342$ \\
$1990 / 91$ & -- & $4,770,057$ & $5,651,648$ & 28.48 & -- \\
Average & & & & 30.11 &
\end{tabular}

Table 4: Channel area data from Marston et al. (2005) recalculated to approximate bankfull channel area. See text for details.

Channel change metrics were calculated for 19 reaches in the study area (Figure 2). Reach 
boundaries were defined by the locations of tributary inflows, channel organization, and the degree of valley confinement. We calculated channel area for the four photo series of our data base for each reach and calculated braid index for each reach for the four series in our data base as well as the data of Mills (1991) and Marston et al. (2005).

\section{Bed Mobility}

We estimated bed mobility by marking tracer rocks on gravel bars and determining the flows when these particles moved. Tracers were marked by painting yellow stripes or circles on exposed bars or by placing painted rocks into the low flow channel prior to the 2005 runoff season. In the latter case, we placed rocks that represented the $\mathrm{D}_{16}, \mathrm{D}_{50}$, and $\mathrm{D}_{84}$ of the gravel bar. We placed 266 particles into the low flow channel and otherwise painted more than 4,800 clasts on exposed bars. Locations of tracers were between JLD and the Oxbow Bend, below Pacific Creek, at Deadmans Bar, and above and below the bridge at Moose (Figure 2). Photographs and surveys before and after the high flows helped relocate painted clasts and track changes in topography. The movement or absence of movement of tracers was recorded periodically during the rise of the spring flood. Once the flood receded and painted clasts were fully exposed, the locations of the clasts were identified and the distance and direction that each had moved was measured. In an effort to generalize the range of flows that initiate bed movement, boundary shear stress $\left(\tau_{0}\right)$ and dimensionless shear stress $\left(\tau^{*}\right)$ were calculated for the locations of tracer injection and the conditions where movement, or no movement, was observed

$$
\begin{aligned}
& \tau_{o}=\rho g h S \\
& \tau^{*}=\tau_{o} /\left(\rho_{s}-\rho\right) g D_{i}
\end{aligned}
$$

where $\rho_{s}, \rho$, and $g$ refer to sediment density, water density and gravitational acceleration respectively, $h$ is the flow depth over the tracers, $S$ is the local slope, and $D_{i}$ is the b-axis diameter of the particles. Surveys of benchmarks and the water surface at flood flow were used to calculate the local slope and depth over the tracers. For each location of painted rocks, we calculated the active proportion of the bed using the classification of Haschenburger and Wilcock (2003). Active proportions less than $10 \%$ were considered immobile, between 10 and $90 \%$ partially mobile, and greater than $90 \%$ fully mobile. Thresholds of dimensionless critical shear stress were calculated for locations changing from one mobility category to another through the high flows.

\section{$\uparrow \quad$ RESUltS}

\section{Hydrology}

The hydrology of the Snake River at the dam during the past century includes 5 periods of relatively high runoff when the annual discharge exceeded the long-term average; this average for the period between 1904 and 2005 is $40.7 \mathrm{~m}^{3} / \mathrm{s}$. The longest consecutive periods of above average runoff occurred near the beginning and end of the measurement period -between 1907 and 1918 when 10 of 12 years were above average and between 1996 and 2001 when there were 6 consecutive years above average. Other periods of high runoff occurred between 1944 and 1956 when there were 9 years of above average runoff, between 1970 and 1976 when there were 6 years above average, and between 1982 and 1986 when there were 5 consecutive years above average. These periods of high average runoff also occurred downstream from Pacific Creek and Buffalo Fork, because the cycles of high and low runoff of these tributaries were in phase with the runoff pattern from further upstream (Fig. 3).

Although the magnitude of the flood regime at the dam between 1916 and 1958 was not significantly different from that predicted for the unregulated flow regime (Fig. 4A, B), the timing of the flood was delayed approximately 2 months so that the largest amount of flows were delivered downstream when irrigation needs were greatest (Fig. $5 \mathrm{~A}$ ). The magnitude of the 2-year recurrence flood was $17 \%$ less than predicted for the unregulated flow regime, and the magnitude of the 10-year recurrence flood was approximately 14\% less than that of the unregulated regime. The mismatch in timing of high dam releases with unregulated floods on tributaries resulted in a $22 \%$ reduction in the 2-year recurrence peak flow between Buffalo Fork and Ditch Creek, because tributary flooding preceded the season of peak dam releases (Table 5). 


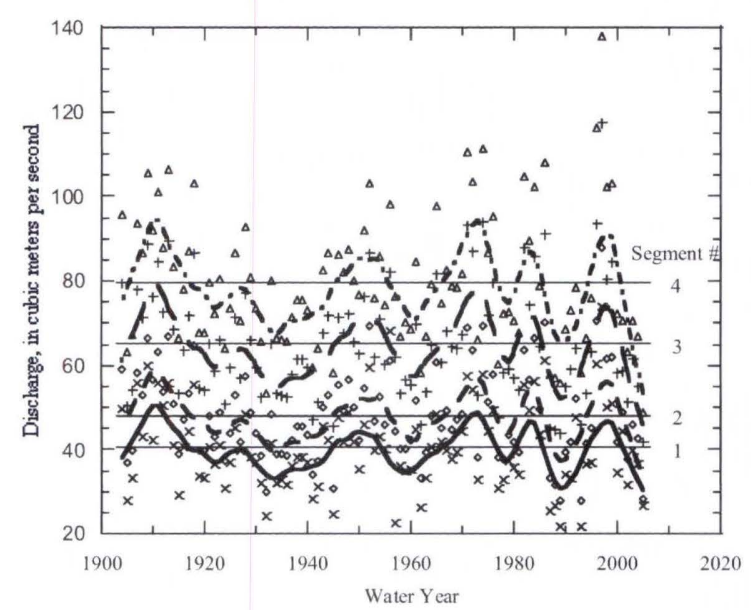

Figure 3. Mean Annual flows for each segment of the Snake River in GTNP. Curved lines are weighted solid horizontal lines are the average discharge over the entire period for each segment.

After 1958, reservoir release rules were changed and lower peak flows were released at approximately the same time that unregulated tributaries were in flood (Fig. 5A). Thus, the magnitude of flood reduction immediately downstream from the dam increased, but the magnitude of flood reduction further downstream was partially offset by tributary inflows. Between 1959 and 2005 , the 2-yr recurrence flood was reduced, in relation to the estimated unregulated flood, by $45 \%$ immediately downstream from the dam, but by only $36 \%$ between Buffalo Fork and Ditch Creek. Thus, the change in operations of JLD that occurred in the late 1950 s caused a very different degree of flood reduction immediately downstream from the dam and elsewhere in the study area. For example, the 2-year recurrence flood between the dam and Pacific Creek was reduced $32 \%$ from that prior to 1958 , but the magnitude of floods downstream from Buffalo Fork only decreased $19 \%$. The duration of flows also changed greatly after 1958 and the characteristics of these changes differed near JLD in relation to further downstream. The duration of base flows of $20 \mathrm{~m}^{3} / \mathrm{s}$ increased after 1958 by $38 \%$ near the dam and by $52 \%$ downstream from Buffalo Fork (Table 6). In contrast, the duration of common floods such as $200 \mathrm{~m}^{3} / \mathrm{s}$ decreased by $80 \%$ near the dam and by $54 \%$ downstream from Buffalo Fork. Thus, the longitudinal pattern of the duration of base flows and common floods differed before and after 1958. Before 1958, the duration of common floods increased $310 \%$ from upstream of Pacific Creek to downstream of Buffalo Fork. After 1958, the duration of this flow increased to a much greater degree -- $850 \%$-- due to the change in timing of high dam releases and tributary inflows.

\begin{tabular}{|c|c|c|c|c|c|c|c|c|}
\hline \multirow{3}{*}{$\begin{array}{l}\text { Recurrence } \\
\text { Interval }\end{array}$} & \multicolumn{2}{|c|}{ Segment 1} & \multicolumn{2}{|c|}{ Segment 2} & \multicolumn{2}{|c|}{ Segment 3} & \multicolumn{2}{|c|}{ Segment 4} \\
\hline & Estimated & & Estimated & & Estimated & & Estimated & \\
\hline & Unregulated & Regulated & Unregulated & Regulated & Unregulated & Regulated & Unregulated & Regulated \\
\hline 1916-1958 & & & & & & & & \\
\hline 1.25 & 217 & 185 & 263 & 211 & 345 & 282 & 387 & 318 \\
\hline 2 & 276 & 230 & 334 & 255 & 434 & 340 & 485 & 381 \\
\hline 5 & 338 & 285 & 409 & 317 & 534 & 419 & 595 & 468 \\
\hline 10 & 371 & 319 & 449 & 358 & 590 & 472 & 656 & 526 \\
\hline $1959-2005$ & & & & & & & & \\
\hline 1.25 & 221 & 126 & 264 & 146 & 336 & 215 & 378 & 243 \\
\hline 2 & 288 & 157 & 349 & 191 & 433 & 276 & 484 & 307 \\
\hline 5 & 352 & 202 & 426 & 252 & 545 & 361 & 606 & 401 \\
\hline 10 & 381 & 234 & 460 & 291 & 608 & 418 & 675 & 467 \\
\hline
\end{tabular}

Table 5: Magnitude of floods $\left(\mathrm{m}^{3} / \mathrm{s}\right)$ of four recurrence intervals for the four segments of the Snake River. Estimated unregulated and regulated values are provided for the periods before and after 1958.

\begin{tabular}{lccccc}
\multicolumn{2}{c}{ Discharge $\left(\mathrm{m}^{3} / \mathrm{s}\right)$} & Segment 1 & Segment 2 & Segment 3 & Segment 4 \\
\hline \multirow{2}{*}{$1916-1958$} & & 121 (days) & 129 & 140 & 150 \\
50 & & 102 & 106 & 112 & 119 \\
100 & & 66 & 76 & 93 & 99 \\
200 & & 10 & 19 & 41 & 54 \\
& $1959-2005$ & 167 & 187 & 213 & 344 \\
50 & & 123 & 132 & 133 & 163 \\
100 & & 39 & 55 & 71 & 109 \\
200 & & 2 & 6 & & 31
\end{tabular}

Table 6: Flow duration (in number of days) for four flows for each segment before and after 1958 

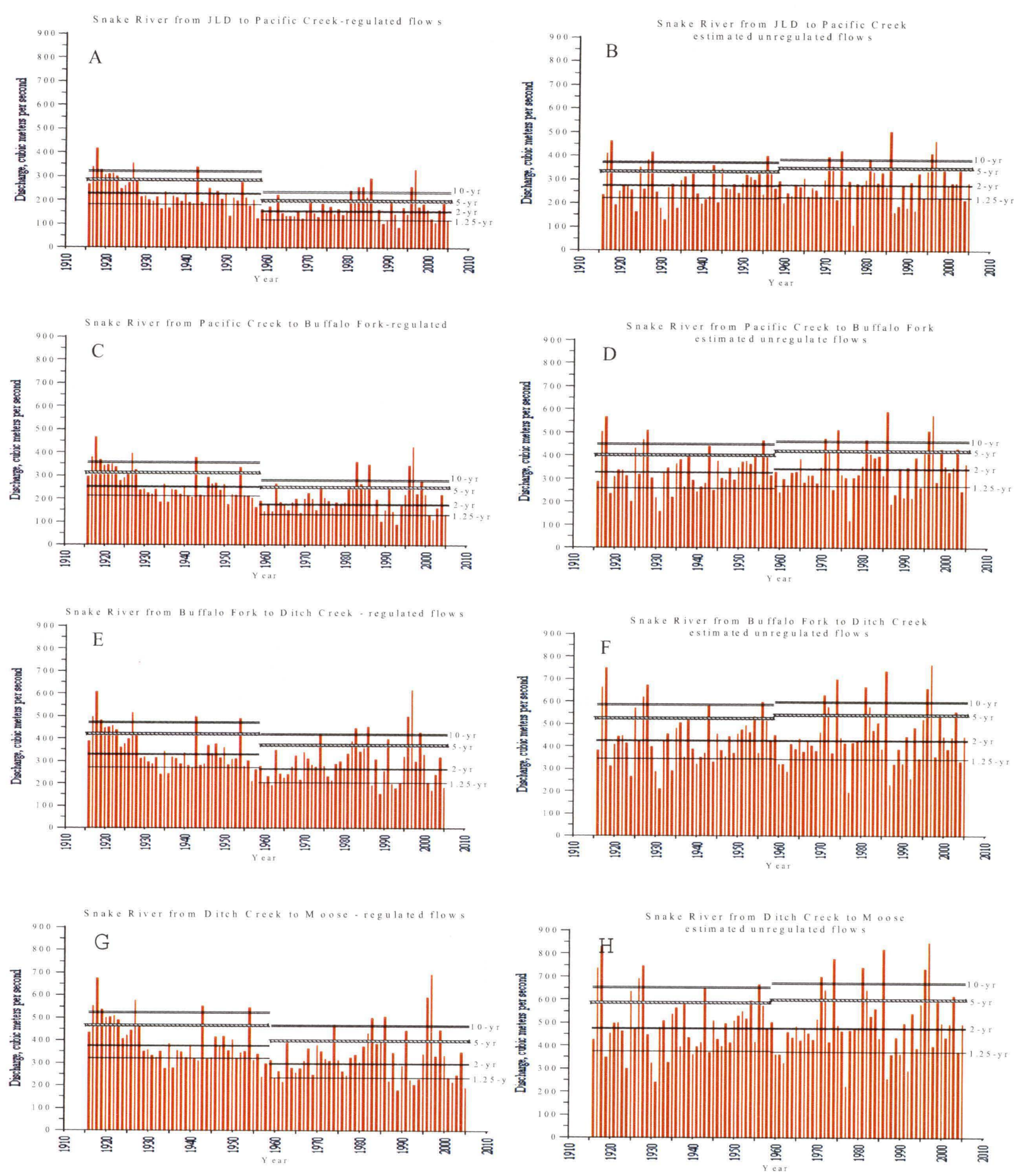

Figure 4: Hydrographs for the Snake River for regulated and estimated unregulated flows for (A,B) Segment 1, (C,D) Segment 2, (E,F) Segment 3 and $(\mathrm{G}, \mathrm{H})$ Segment 4. Data based on highest mean daily flow for each year 1916-2005. Magnitudes of floods of 4 recurrence intervals for before and after 1958 are shown. 

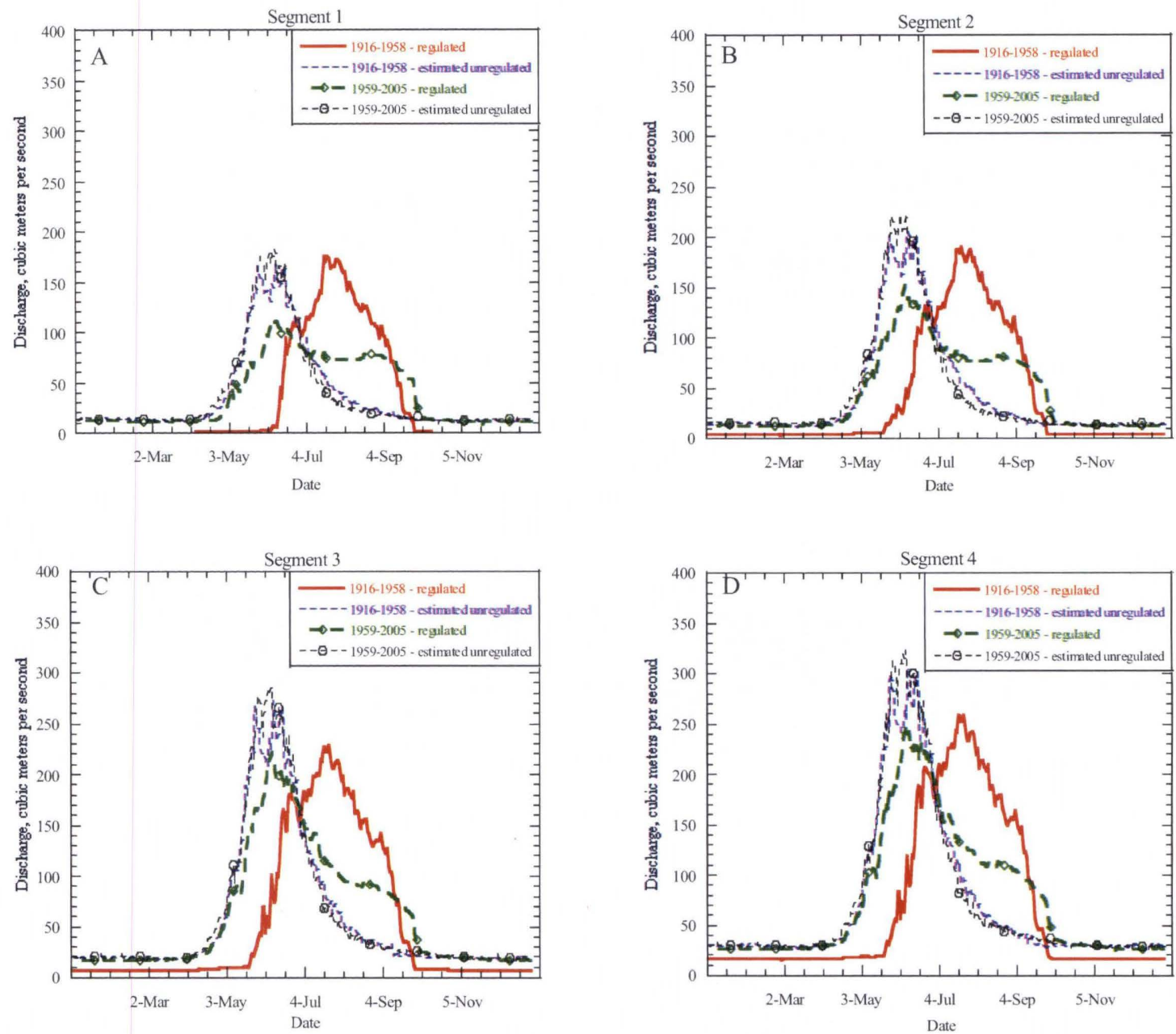

Figure 5: Hydrographs for regulated and estimated unregulated flows before and after 1958 for each segment of the Snake River. Data based on mean daily discharge.

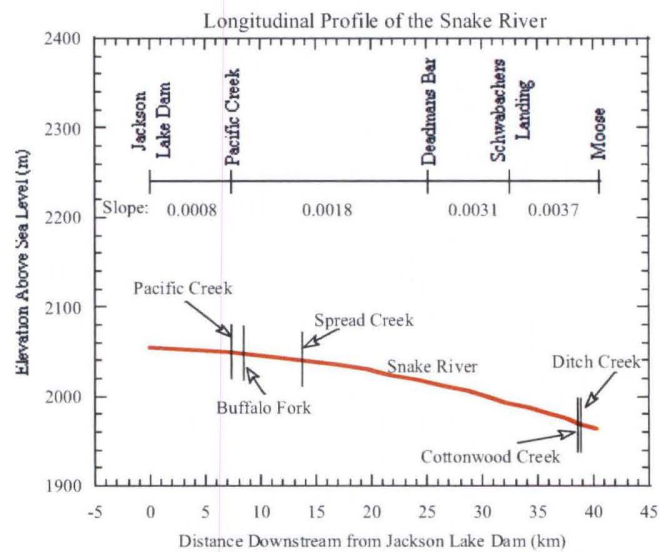

Figure 6: Longitudinal profile of the Snake River from JLD to Moose with tributaries and changes in slope superimposed.

\section{DISCUSSION}

The changes to the hydrologic regime of the Snake River in GTNP are relatively small compared to some regulated rivers in the western United States. Since the flow regime change in 1958, the 2-yr flood of the Snake River immediately below JLD decreased $32 \%$. Regulation of Glen Canyon Dam resulted in a $65 \%$ decrease of peak flows on the Colorado River (Stevens et al., 1995), that of Flaming Gorge Dam a $57 \%$ decrease in the 2-yr flood on the Green River (Grams and Schmidt, 2002), and that of many small diversions a $53 \%$ decrease in stream flow on the lower Duchesne River (Gaeuman et al., 2005). Flow contributions of unregulated tributaries caused the magnitude of decreases in flows on the Snake River in 
GTNP to reduce to $25 \%$ below Pacific Creek and $19 \%$ below Buffalo Fork. This means the flow regime change in 1958 reduced flows by only $19 \%$ for 35.2 of the $43.4 \mathrm{~km}$ of the Snake River in GTNP.

Due to this relatively small change in the flow regime of the Snake River in GTNP, minor longterm impacts to the geomorphology of the Snake River alluvial valley might be expected.

The longitudinal profile of the Snake River from JLD to Moose must be considered in a discussion of downstream trends. The entrance of the tributaries Pacific Creek and Buffalo Fork coincide with a substantial increase in channel gradient from 0.0008 below JLD to 0.0018 below Pacific Creek, $7 \mathrm{~km}$ downstream (Figure 6). The gradient continues to increase below Deadmans Bar (0.0031) and Schwabachers Landing (0.0038), 25 and $33 \mathrm{~km}$ downstream of JLD respectively. These changes in gradient should result in increased bed mobility, braiding, and channel change with downstream distance from JLD. Because of this, the channel change analysis of individual reaches is important in identifying reaches and periods of time of increased deposition or erosion. Though the channel change and bed transport studies will help determine if the Snake River is capable of transporting sediment delivered by tributaries, a sediment budget for the Snake River and tributaries is necessary for a more complete understanding.

\section{$\downarrow$ Literature Cited}

Andrews, E.D. 1980. Effective and Bankfull Discharges in the Yampa River Basin, Colorado and Wyoming. Journal of Hydrology 46: 311330 .

Andrews, E.D. 1984. Bed-material entrainment and hydraulic geometry of gravel-bed rivers in Colorado. GSA Bulletin 95; 3; p. 371-378.

Church, M. 1995. Geomorphic Response to River Flow Regulation: Case Studies and Time-Scales. Regulated Rivers: Research and Management11, $3-22$.

Everitt, B. 1993. Channel Responses to Declining Flow on the Rio Grande between FT. Quitman and Presidio, Texas. Geomorphology 6, 225-242.

Gaeuman, D.A., J.C. Schmidt and P.R. Wilcock. 2003. Evaluation of In-Channel Gravel Storage with Morphology-Based Gravel Budgets
Developed from Planimetric Data. Journal of Geophysical Research 108 (F1), 6001, doi:10.1029/2002JF000002).

Gaeuman, D., J.C. Schmidt and P.R. Wilcock. 2005. Complex Channel Responses to Changes in Stream Flow and Sediment Supply on the Lower Duchesne River, Utah. Geomorphology 64, 185206.

Galay, V.J. 1983. Causes of Bed Degradation. Water Resources Research 19:5. 1057-1090.

Grams, P.E. and J.C. Schmidt. 2002. Streamflow Regulation and Multi-Level Flood Plain Formation: Channel Narrowing on the Aggrading Green River in the Eastern Uinta Mountains, Colorado and Utah. Geomorphology 44, 337-360.

Grams, P.E. and J.C. Schmidt. 2005. Equilibrium or Indeterminate? Where Sediment Budgets Fail: Sediment Mass Balance and Adjustment of Channel Form, Green River Downstream from Flaming Gorge Dam, Utah and Colorado. Geomorphology 71, 156-181.

Grant, G.E., J.C. Schmidt and S.L. Lewis. 2003. A Geological Framework for Interpreting Downstream Effects of Dams on Rivers. In: O'Conner, J.E., Grant, G.E., A Peculiar River: Geology, Geomorphology, and Hydrology of the Deschutes River, Oregon. American Geophysical Union, Washington, D.C., 203-219.

Haschenburger, J.K. and P.R. Wilcock, P. 2003. Partial Transport in a Natural Gravel Bed Channel. Water Resources Research 39:1, 1020, doi:10.1029/2002WR001532.

Interagency Advisory Committee on Water Data. 1982. Guidelines for Determining Flood Flow Frequency, Bulletin \#17B of the Hydrology Subcommittee. U.S. Department of the Interior. Reston, VA.

Komura, S. and D.B. Simmons. 1967. River-bed Degradation Below Dams. Journal of the Hydraulics Division, Proceedings of the American Society of Civil Engineers HY4, 1-14.

Lagasse, P.F. 1981. Geomorphic Response of the Rio Grande to Dam Construction, New Mexico Geological Society, Special Publication No. $10,27-46$. 
Leopold, L.B. 1994. A View of the River. Harvard University Press, Cambridge, MA, 298 pp.

Linsley, R.K., M.A. Kohler and J.L.H. Paulhus. 1982. Hydrology for Engineers. McGraw-Hill, New York, NY, 508 p.

Love, D.L., J.C Reed, and K.L. Pierce. 2003. Creation of the Teton Landscape: A Geological Chronicle of Jackson Hole and The Teton Range. Grand Teton Natural History Association. Moose, WY. 132p.

Marston, R.A., J.D. Mills, D.R. Wrazien, B. Bassett and D.K. Splinter. 2005. Effects of Jackson Lake Dam on the Snake River and its floodplain, Grand Teton National Park, Wyoming, USA. Geomorphology, 71, 79-98.

Mills, J.D. 1991. Wyoming's Jackson Lake Dam, Horizontal Channel Stability, and Floodplain Vegetation Dynamics. Masters Thesis from the University of Wyoming. Laramie, WY. 54 p.

Mostafa, M.G. 1957. River-Bed Degradation Below Large-Capacity Reservoirs. American Society of Civil Engineers Transactions, paper no. 2879, 122, 688-704.
Nanson, G.C. and J.C. Croke. 1992. A Genetic Classification of Floodplains. Geomorphology 4, 459-486.

Stevens, L.E., J.C. Schmidt, T.J. Ayers and B.T. Brown. 1995. Flow Regulation, Geomorphology, and Colorado River Marsh Development in the Grand Canyon, Arizona. Ecological Applications 5:4. 1025-1039.

U.S. Fish and Wildlife Service and Hoopa Valley Tribe. 1999. Trinity River Flow Evaluation Final Report, 308 pp.

Williams, G.P. and M.G. Wolman. 1984. Downstream Effects of Dams on Alluvial Rivers. Geological Survey Professional Paper 1286, 83 pp.

Wolman, M.G. and J.P. Miller. 1960. Magnitude and Frequency of Forces in Geomorphic Processes. Journal of Geology 68:1. 54-74. 